九州大学学術情報リポジトリ

Kyushu University Institutional Repository

\title{
Toxonic Re-examination of the Apodemus agrarius chejuenis, Comparing External and Crinical Morphological Characters among Four Asian Apodemus Species
}

Oh, Hong-Shink

Educational Research Institute, Department of Science Education, Cheju National University

Yoshinaga, Yuko

Laboratory of Human Biology, Oita University of Nursing and Health Sciences

Kaneko, Takane

Laboratory of Zoology, Division of Zoology and Entomology, Department of Applied Genetics and Pest Management, Graduate School of Bioresource and Bioenvironmental Sciences, Kyushu University

Iida, Hiroshi

Laboratory of Zoology, Division of Zoology and Entomology, Department of Applied Genetics and Pest Management, Faculty of Agriculture, Kyushu University

他

https://doi.org/10.5109/4508

出版情報：九州大学大学院農学研究院紀要. 47 (2)，pp.373-386，2003-02-01. Faculty of Agriculture, Kyushu University

バージョン :

権利関係 : 


\title{
Taxonomic Re-examination of the Apodemus agrarius chejuensis, Comparing External and Cranial Morphological Characters among Four Asian Apodemus Species
}

\author{
Hong-Shik OH', Yuko YOSHINAGA*, Takane KANEKO**, \\ Hiroshi IIDA*** and Takayuki MŌRI*** \\ Laboratory of Zoology, Division of Zoology and Entomology, Department of \\ Applied Genetics and Pest Management, Faculty of Agriculture, Kyushu \\ (Received October 31, 2002 and accepted November 15, 2002)
}

\begin{abstract}
In order to re-examine the taxonomic position of the Korean striped field mouse, Apodemus agrarius chejuensis from the Cheju Island, external value and skull characters were compared among $A$. agrarius coreae from the Korean Peninsula, $A$. speciosus, $A$. argenteus, and $A$. semotus. Skull characters of $A$. agrarius chejuensis (Cheju population) and $A$. agrarius coreae (mainland population) were fitted onto different clines. In paticular, distances between the posterior end of incisive foramina and anterior end of the first upper molar were critically different between these two subspecies. These evidences support the specific division of 'Apodemus chejuensis' for the population inhabiting the Cheju Island from A. agrarius in the mainland, as proposed by Koh and Yoo(1992).
\end{abstract}

\section{INTRODUCTION}

The striped field mouse, Apodemus agrarius, widely distributes across the temperate region of the Eurasia (Corbet, 1978), including 22 subspecies (Musser and Carleton, 1993). This mouse is the most common species in wild rodents in Korea (Hong and Lee, 1984), showing considerable geographic variations in morphology. Thomas (1907) first described the striped field mouse in the Korean Peninsular. He did not state any critical differences in the external morphometric characters between the populations from Korean mainland and the Cheju Island, and classified the Korean striped field mouse as a single subspecies, Micromys agrarius mantchuricus. Thereafter, the species was assigned to a genus Apodemus, and the Korean population has been morphologically classified into two or four subspecies. Johnson and Jones (1955) identified two subspecies, Apodemus agrarius pallescens and A. a. chejuensis, while Kuroda (1934) and Won (1961) did A. a. manchuria and A. a. coreae. Jones and Johnson (1965) divided into four subspecies, $A$. a. manchuria in the extreme northern Korea, $A$. a. coreae in the

${ }^{\dagger}$ Educational Research Institute, Department of Science Education, Cheju National University, Jeju, Jeju-do, 690-756, Korea

* Laboratory of Human Biology, Oita University of Nursing and Health Sciences

** Laboratory of Zoology, Division of Zoology and Entomology, Department of Applied Genetics and Pest Management, Graduate School of Bioresource and Bioenvironmental Sciences, Kyushu University

*** Laboratory of Zoology, Division of Zoology and Entomology, Department of Applied Genetics and Pest Management, Faculty of Agriculture, Kyushu University

† Corresponding to: Dr. Hong -Shik Oh (TEL: 82-64-754-3283, E-mail. sciedu@cheju.cheju.ac.kr) 
major part of Korea, A. a. pallescens in the coastal lowlands of southern and southwestern Korea, and $A$. a. chejuensis in the Cheju Island.

Tsuchiya (1984, 1985) performed cytogenetic and biochemical analyses for Apodemus spp. aiming to produce new experimental animals, and found transferrin polymorphism among those four subspecies. A series of papers written by Koh and colleagues, however, have been insisted that the population of the striped field mouse in the Cheju Island should be classified into another species. They found morphological difference between $A$. agrarius chejuensis and A. agrarius coreae (Koh, 1986) or other Asian seven subspecies (Koh, 1991). Moreover, in RFLPs analyses of mitochondorial DNA, $A$. agrarius chejuensis and $A$. agrarius coreae assigned to different subgroups (Koh and Yoo, 1992). However, there is no consensus up to this time on the classification of the population of the striped field mouse in the Cheju Island.

There are many reports on inter- and intra-specific variations in the cranial and external morphometric characters for various Apodemus spp., A. agrarius: (Haitlinger, 1962; Adamczewska-Andrzejewska, 1971, 1973; Sikorski, 1982) and A. sylvaticus: (Delany and Davis, 1961; Haitlinger, 1969; Delany, 1970; Gurnell and Knee, 1984) in Europe, A. speciosus (Imaizumi, 1962; Miyao et al., 1968; Yoshida, 1983) and A. argenteus (Miyao and Mōri, 1968; Yoshida, 1984) in Japan, A. semotus (Lin et al., 1992) in Taiwan. Comparing with these Apodemus spp., data for A. agrarius were constricted, especially for $A$. agrarius chejuensis. Thus, it seems to be important to show detailed morphological data of $A$. agrarius in order to clarify the taxonomic problem of $A$. agrarius chejuensis population.

The purpose of this study is to give some evidences to clarify the classification of the Cheju-Island population of the striped field mouse, by showing intra-specific and inter-specific variations in body and cranial characters. Originally, the population of $A$. agrarius in the Cheju Island had been classified to a subspecies because of their large body size compared to other $A$. agrarius. In this study, we focus on the proportional differences in morphology between $A$. agrarius chejuensis and A. agrarius coreae. We also compared these data with those of three other Asian species, $A$. speciosus and $A$. argenteus in Japan and $A$. semotus in Taiwan to demonstrate the inter-specific variation of Asian Apodemus spp. and to evaluate the differences between $A$. agrarius chejuensis and $A$. agrarius coreae.

\section{MATERIALS AND METHODS}

To show inter-specific morphological variations in Asian Apodemus, 40 samples consisted of 20 males and 20 females were collected in the field for each of $A$. agrarius chejuensis, $A$. agrarius coreae, $A$. speciosus, $A$. argenteus, and A. semotus. A. agrarius chejuensis was captured at Mt. Halla of Cheju Island in Korea, from March to August, 1994. A. agrarius coreae was captured at Mt. Whangreung in Pusan in Korea from August to September, 1994. A. speciosus and A. argenteus were captured at Mt. Abura at Fukuoka in Japan in November and December, 1994, respectively. A. semotus was captured at the Alishan Alpine Forest Park in Taiwan in April, 1986. These samples of $A$. semotus were measured their body size and conserved in $70 \%$ alcohol. Adults were determined by the degree of wear of the upper $1 \mathrm{st}, 2 \mathrm{nd}$ and $3 \mathrm{rd}$ molars based on Hikida 


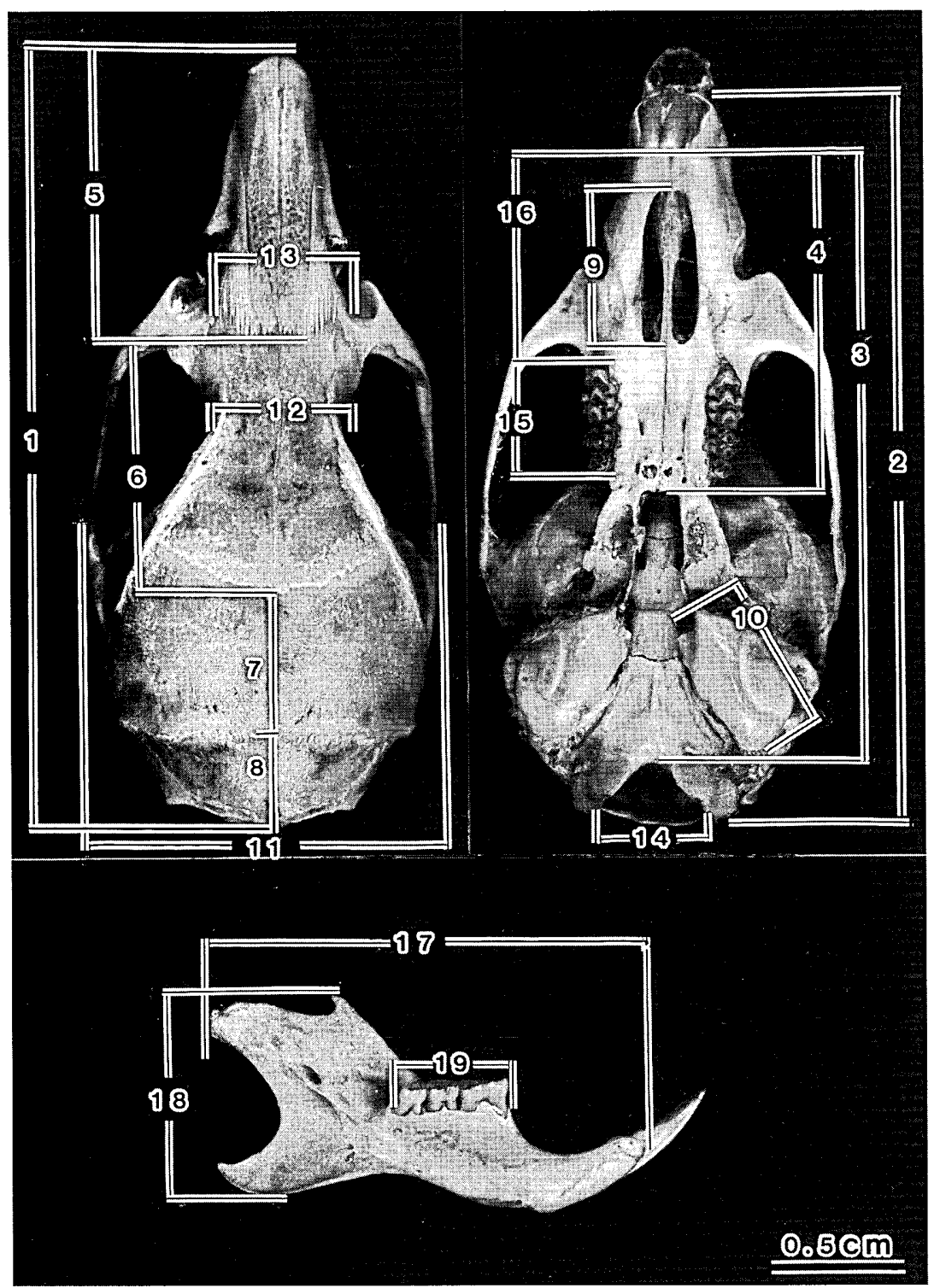

Fig. 1. The skull of genus Apodemus showing the the cranial and mandibular measurements. 1) Greatest length (GL); 2) Condylobasal length (CL); 3) Basilar length (BL); 4) Palatilar length (PL); 5) Nasal length (NL); 6) Frontal length (FL); 7) Parietal length (PrL); 8) Interparietal length (IL); 9) Length of incisive foramen (LIF); 10) Auditory bulla length (ABL); 11) Zygomatic breadth (ZB); 12) Interorbital breadth (IB); 13) Breadth of rostrum (BR); 14) Breadth of occipital foramen (BOF); 15) Length of upper molar series (LUM); 16) Length of upper diastema (LUD); 17) Length of mandible (LM); 18) Height of mandible (HM); 19) Length of lower molar series (LLM). 
and Murakami (1980). To show external morphological characteristics, five variables were measured for each specimen: weight, head and body length, tail length (from the anus to the end of the tail), hind foot length (without claws) and ear length. After external morphometry, we prepared cranial specimens and measured 19 parts of skull (Fig. 1) with digital Vernier calipers to the nearest $0.01 \mathrm{~mm}$. In addition, sexual dimorphism in size is also considered as a specific characteristics.

Results are expressed as mean $1 \pm$ SD. The differences of averages in body and cranial measurements were tested by ANOVA. To show the proportional difference, partial lengths of body were regressed on total length (head and body length) and those of skull were regressed on the greatest length of the skull. We estimated the slopes and Y-intercepts of regression lines for each species/subspecies. The slopes of these lines were compared by t-test between all dyad combinations of examined five species/subspecies. When there was no significant differences, we tested the Y-intercepts (Zar, 1998). Differences between each part of the body and skull size of males and females were compared by unpaired t-tests.

\section{RESULTS}

\section{Body size comparisons}

Using head and body length as an index of body size, we found that there are significantly different among the five species/subspecies (ANOVA, $F=102.9, d . f .=4,195, p<$ $0.0001)$. A. speciosus (111.94 $\pm 8.21 \mathrm{~mm}$ ) was the largest species, followed by $A$. agrarius chejuensis $(103.07 \pm 7.38 \mathrm{~mm})$, A. semotus $(101.59 \pm 3.99 \mathrm{~mm})$, A. agrarius coreae $(88.47 \pm 12.00 \mathrm{~mm})$ and $A$. argenteus $(80.45 \pm 4.83 \mathrm{~mm})$. In post-hoc tests, there were significant differences between all dyads species/subspecies $(p<0.0001)$ with the excep-

Table 1. Statistical differences ( $t$-test, Zar, 1984) among regression lines of three body measurements and the greatest length of the skull against the head and body length in five species and two subspecies of Apodemus. Differences of the regression coefficients (R) and the Yintercepts $(\mathrm{I})$ are shown for dyad with $\mathrm{p}<0.05$. Y-intercepts were tested for dyad with equal regression coefficients

\begin{tabular}{|c|c|c|c|c|c|c|}
\hline \multicolumn{2}{|c|}{ Dyad } & \multirow{2}{*}{$\begin{array}{c}\begin{array}{c}\text { Body weight } \\
\text { (g) }\end{array} \\
\text { I }\end{array}$} & \multirow{2}{*}{$\begin{array}{c}\begin{array}{c}\text { Tail length } \\
\text { (mm) }\end{array} \\
\text { I }\end{array}$} & \multirow{2}{*}{$\begin{array}{c}\text { Hind foot } \\
\text { length }(\mathrm{mm})\end{array}$} & \multirow{2}{*}{$\begin{array}{c}\begin{array}{c}\text { Ear length } \\
\text { (mm) }\end{array} \\
\text { I }\end{array}$} & \multirow{2}{*}{$\begin{array}{c}\begin{array}{c}\text { Greatest } \\
\text { length } \\
\text { of skull } \\
\text { (mm) }\end{array} \\
\text { I }\end{array}$} \\
\hline A. a. chejuensis & : A. a. coreae & & & & & \\
\hline A. a. chejuensis & : A. speciosus & $\mathrm{R}$ & I & I & I & ns \\
\hline A. a. chejuensis & : A. argenteus & I & I & I & I & $\mathrm{R}$ \\
\hline A. a. chejuensis & : A. semotus & I & I & I & I & $\mathrm{R}$ \\
\hline A. a. coreae & : A. speciosus & $\mathrm{R}$ & $\mathrm{R}$ & I & $\mathrm{R}$ & $\mathrm{R}$ \\
\hline A. a. coreae & : A. argenteus & I & I & I & I & I \\
\hline A. a. coreae & : A. semotus & I & I & I & I & $\mathrm{R}$ \\
\hline A. speciosus & : A. argenteus & $\mathrm{R}$ & I & I & I & $\mathrm{R}$ \\
\hline A. speciosus & : A. semotus & I & I & ns & I & $\mathrm{R}$ \\
\hline A. argenteus & : A. semotus & $\mathrm{R}$ & ns & I & ns & $\mathrm{R}$ \\
\hline
\end{tabular}



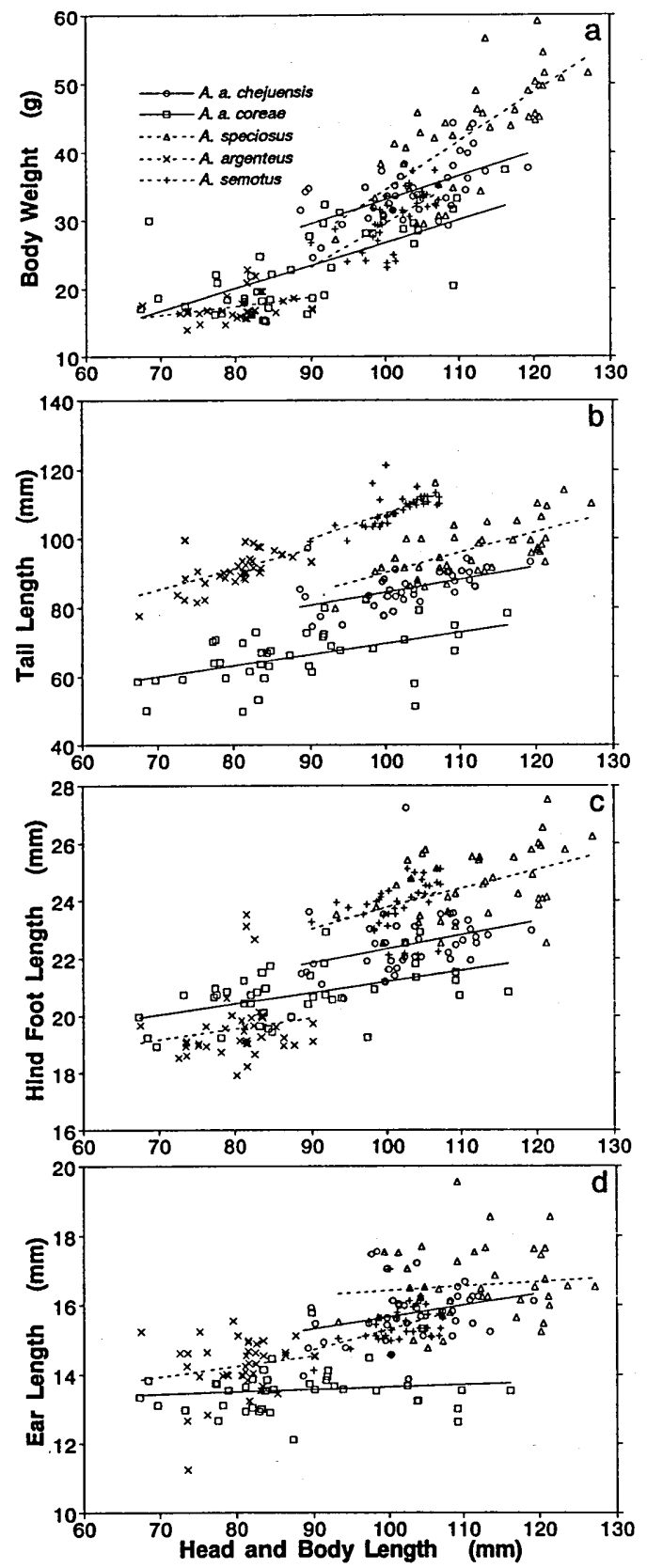

Fig. 2. The relationships of the difference between a) body weight; b) tail length; c) hind foot length; d) ear length against head and body length of the external morphological traits in Apodemus. 
tion between $A$. agrarius. chejuensis and A. semotus $(p=0.40)$. The head and body length of $A$. agrarius. chejuensis was $16.5 \%$ longer than that of $A$ agrarius. coreae. Similar tendency was observed in body weight (Table 1), in which A. agrarius. chejuensis $(34.11 \pm 4.34 \mathrm{~g}$ ) was $48.9 \%$ heavier than $A$. agrarius. coreae $(22.91 \pm 6.00 \mathrm{~g})$.

Most of the regression lines of the tail lengths, hind foot lengths and ear lengths on head and body lengths (Fig. 2) were significantly different among five species/subspecies (Table 1). That indicates the proportions of these body parts were different among the species/subspecies, including between $A$. agrarius chejuensis and $A$. agrarius coreae. Especially, the tail and ear were remarkably short in $A$. agrarius coreae, that is known as common characteristics in $A$. agrarius.

In sexual dimorphism in body size, generally male-dominant dimorphism was found in Apodemus spp. (Table 2). A. semotus indicated the greatest male-dominant dimorphism in all measurements, while $A$. speciosus indicated low sexual dimorphism. However, $A$. argenteus alone indicated female-dominant sexual dimorphism. Between $A$. agrarius chejuensis and $A$. agrarius coreae, there was not so clear difference in sexual dimorphism in body size.

Table 2. Sexual dimorphism in five measurements of body size in four species and two subspecies of Apodemus. Larger sexes are shown with the significant levels $\left(t\right.$-test, ${ }^{*} \mathrm{p}<0.05,{ }^{* *} \mathrm{p}<0.01$, $* * * \mathrm{p}<0.001$ )

\begin{tabular}{|c|c|c|c|c|c|c|}
\hline & \multicolumn{3}{|c|}{ Body weight (g) } & \multicolumn{3}{|c|}{ Head and body length (mm) } \\
\hline & male & female & larger sex & male & female & larger sex \\
\hline A. a. chejuensis & $36.80 \pm 3.63$ & $31.42 \pm 3.19$ & male ${ }^{* * *}$ & $105.53 \pm 7.91$ & $100.61 \pm 6.04$ & male* \\
\hline A. a. coreae & $27.68 \pm 4.66$ & $18.15 \pm 2.12$ & male*** & $93.89 \pm 12.45$ & $83.05 \pm 8.87$ & male** \\
\hline A. speciosus & $45.58 \pm 7.91$ & $40.26 \pm 6.97$ & male* & $115.14 \pm 6.94$ & $108.74 \pm 8.28$ & male* \\
\hline A. argenteus & $16.64 \pm 1.33$ & $18.38 \pm 2.07$ & female** & $79.03 \pm 4.08$ & $81.87 \pm 5.19$ & \\
\hline A. semotus & $32.98 \pm 2.81$ & $28.11 \pm 3.22$ & male*** & $103.34 \pm 4.60$ & $99.84 \pm 2.26$ & male*** \\
\hline
\end{tabular}

\begin{tabular}{|c|c|c|c|c|c|c|}
\hline & \multicolumn{3}{|c|}{ Tail length (mm) } & \multicolumn{3}{|c|}{ Hind foot length (mm) } \\
\hline & male & female & larger sex & male & female & larger sex \\
\hline A. a. chejuensis & $87.85 \pm 3.85$ & $83.49 \pm 5.56$ & male** & $22.60 \pm 0.68$ & $22.37 \pm 1.41$ & \\
\hline A. a. coreae & $67.85 \pm 9.44$ & $64.12 \pm 5.72$ & & $21.01 \pm 1.09$ & $20.51 \pm 0.72$ & \\
\hline A. speciosus & $98.95 \pm 7.32$ & $95.34 \pm 8.54$ & & $24.58 \pm 1.26$ & $24.55 \pm 1.22$ & \\
\hline A. argenteus & $90.53 \pm 4.89$ & $92.23 \pm 5.54$ & & $19.22 \pm 0.41$ & $19.91 \pm 1.53$ & \\
\hline A. semotus & $110.64 \pm 4.36$ & $106.61 \pm 3.74$ & male** & $24.32 \pm 0.75$ & $23.48 \pm 0.68$ & male*** \\
\hline
\end{tabular}

\begin{tabular}{lccl}
\hline & \multicolumn{3}{c}{ Ear length (mm) } \\
\cline { 2 - 4 } & male & female & larger sex \\
\hline A. a. chejuensis & $15.78 \pm 0.76$ & $15.74 \pm 0.89$ & \\
A. a. coreae & $13.72 \pm 0.78$ & $13.41 \pm 0.53$ & \\
A. speciosus & $16.75 \pm 0.96$ & $16.38 \pm 1.15$ & \\
A. argenteus & $13.85 \pm 0.85$ & $14.66 \pm 0.51$ & female** $^{* *}$ \\
A. semotus & $15.60 \pm 0.61$ & $15.22 \pm 0.31$ & male* $^{*}$ \\
\hline
\end{tabular}




\section{Interspecific comparison of cranial size}

Comparing the external appearance of the skull specimens, the skulls of $A$. agrarius chejuensis and $A$. speciosus were characterized by their large size. There was a pair of

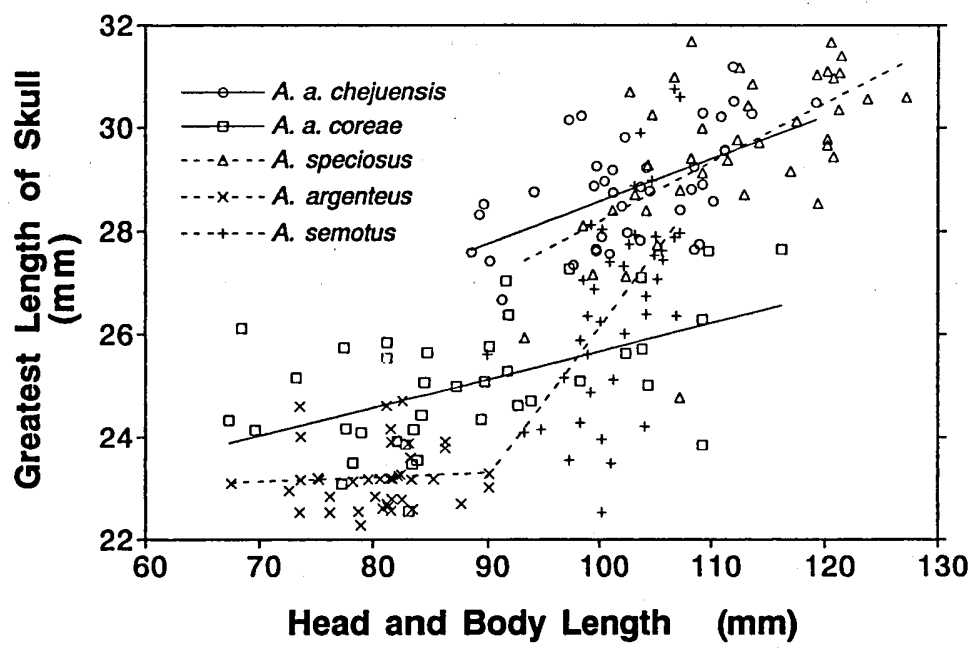

Fig. 3. The relationship between the greatest length of the skull and the head and body length in Apodemus.

Table 3. Sexual dimorphism ( $t$-test) in 19 measurements of skull in two subspecies of Apodemus agrarius and other three Apodemus species. Values indicate the remainders which subtracted female average values form male ones

\begin{tabular}{lccccc}
\hline \multicolumn{1}{c}{ Measurements } & A. a. chejuensis & A. a. coreae & A. speciosus & A. argenteus & A. semotus \\
\hline GLS: greatest length of skull & $0.74 \mathrm{~ns}$ & $1.31^{* * *}$ & $0.28 \mathrm{~ns}$ & $-0.02 \mathrm{~ns}$ & $1.95^{* * *}$ \\
CL: condylobasal length & $0.75^{*}$ & $0.97^{* *}$ & $0.34 \mathrm{~ns}$ & $-0.19 \mathrm{~ns}$ & $1.66^{* *}$ \\
BL: basilar length & $0.58 \mathrm{~ns}$ & $1.28^{* * *}$ & $-0.07 \mathrm{~ns}$ & $-0.18 \mathrm{~ns}$ & $1.48^{*}$ \\
PL: palatilar length & $0.27 \mathrm{~ns}$ & $0.54^{* * *}$ & $0.15 \mathrm{~ns}$ & $-0.08 \mathrm{~ns}$ & $1.05^{* *}$ \\
NL: nasal length & $0.42^{*}$ & $0.48^{* * *}$ & $-0.09 \mathrm{~ns}$ & $0.26 \mathrm{~ns}$ & $1.33^{* *}$ \\
FL: frontal length & $0.00 \mathrm{~ns}$ & $0.56^{* *}$ & $-0.21 \mathrm{~ns}$ & $0.12 \mathrm{~ns}$ & $0.12 \mathrm{~ns}$ \\
PrL: pariental length & $0.10 \mathrm{~ns}$ & $-0.06 \mathrm{~ns}$ & $-0.05 \mathrm{~ns}$ & $0.06 \mathrm{~ns}$ & $0.31 \mathrm{~ns}$ \\
IL: interpariental length & $0.14 \mathrm{~ns}$ & $0.15 \mathrm{~ns}$ & $0.14 \mathrm{~ns}$ & $0.04 \mathrm{~ns}$ & $-0.03 \mathrm{~ns}$ \\
LIF: length of incisive foramen & $0.23 \mathrm{~ns}$ & $0.09 \mathrm{~ns}$ & $0.13 \mathrm{~ns}$ & $-0.04 \mathrm{~ns}$ & $0.41^{* *}$ \\
ABL: auditory bulla length & $-0.03 \mathrm{~ns}$ & $0.02 \mathrm{~ns}$ & $0.07 \mathrm{~ns}$ & $-0.04 \mathrm{~ns}$ & $0.30^{*}$ \\
ZB: zygomatic breadth & $0.21 \mathrm{~ns}$ & $0.55^{* * *}$ & $-0.02 \mathrm{~ns}$ & $-0.20^{*}$ & $0.63^{*}$ \\
IB: interorbital breadth & $0.08 \mathrm{~ns}$ & $0.03 \mathrm{~ns}$ & $0.06 \mathrm{~ns}$ & $0.05 \mathrm{~ns}$ & $0.21^{*}$ \\
BR: breadth of rostrum & $0.06 \mathrm{~ns}$ & $0.05 \mathrm{~ns}$ & $0.08 \mathrm{~ns}$ & $0.03 \mathrm{~ns}$ & $0.26^{*}$ \\
BOF: breadth of occipital foramen & $-0.06 \mathrm{~ns}$ & $-0.19^{*}$ & $0.30 \mathrm{~ns}$ & $-0.02 \mathrm{~ns}$ & $-0.02 \mathrm{~ns}$ \\
LUM: length of upper molar series & $-0.05 \mathrm{~ns}$ & $0.05 \mathrm{~ns}$ & $0.11 \mathrm{~ns}$ & $0.04 \mathrm{~ns}$ & $0.24^{*}$ \\
LUD: length of upper diastema & $0.22 \mathrm{~ns}$ & $0.44^{* *}$ & $0.34 \mathrm{~ns}$ & $-0.02 \mathrm{~ns}$ & $0.68^{* *}$ \\
LM: length of mandible & $0.36 \mathrm{~ns}$ & $0.81^{* * *}$ & $0.15 \mathrm{~ns}$ & $0.12 \mathrm{~ns}$ & $0.99^{* *}$ \\
HM: height of mandible & $0.21 \mathrm{~ns}$ & $0.68^{* * *}$ & $-0.06 \mathrm{~ns}$ & $-0.01 \mathrm{~ns}$ & $0.51^{*}$ \\
LLM: length of lower molar series & $-0.11 \mathrm{~ns}$ & $-0.03 \mathrm{~ns}$ & $0.08 \mathrm{~ns}$ & $0.11^{*}$ & $0.25^{*}$ \\
\hline
\end{tabular}

${ }^{*} \mathrm{p}<0.05,{ }^{* *} \mathrm{p}<0.01,{ }^{* * *} \mathrm{p}<0.001, \mathrm{~ns}:$ statistically non-significant $(\mathrm{p}>0.05)$ 
lateral processus in the posterior part of the skull in $A$. speciosus only. The rostrum of $A$. agrarius chejuensis was long and narrow, while that of $A$. speiosus was long and wedge-shaped constricted at the center. The skull of $A$. semotus was intermediate size. The skulls of $A$. agrarius coreae and $A$. argenteus were small. In $A$. argenteus, the rostrum was long and a braincase was relatively flat.

In order to carry out interspecific comparisons of relative cranial size, we estimated the regression lines of the greatest length of the skull on the head and body length. $A$. agrarius chejuensis and $A$. speciosus showed similar distribution, forming a group with relatively large skull (Fig. 3), and the estimated regression lines were not different, while there were significant differences in the linear regression between other dyads (Table 3). The regression coefficient was greatest in $A$. semotus, because of their large variation in

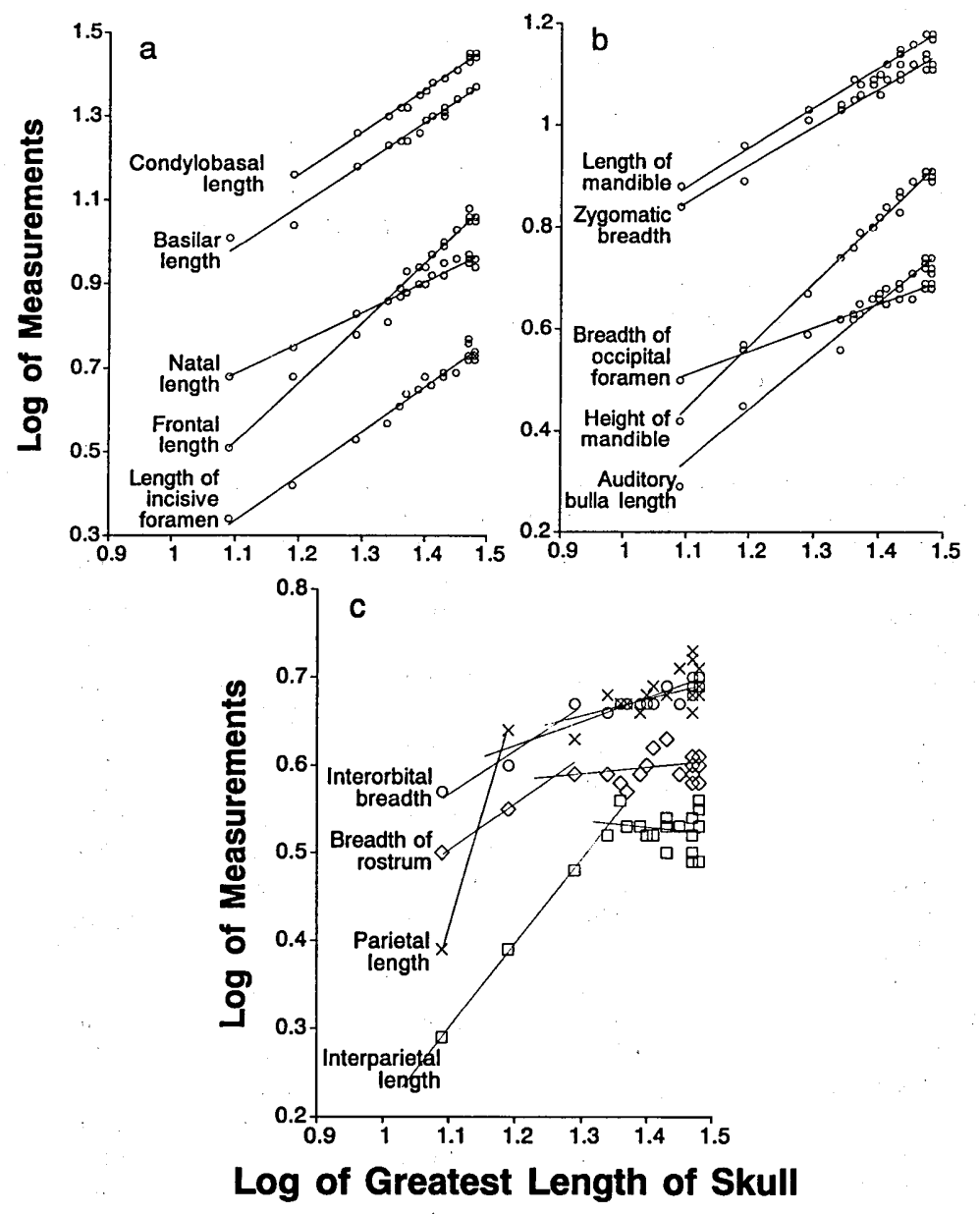

Fig. 4. Relative growth of the 14 skull measurements against the greatest length of the skull in Apodemus agrarius chejuensis. 
skull size. The regression line of $A$. agrarius. coreae was significantly different from that of $A$. agrarius chejuensis (Table 3 ), showing proportional difference in skull size relative to body size. A. argenteus constituted a smallest skull group with small variation (Fig. 3).

Comparing the percentages of 18 lengths to the greatest length of the skull between $A$. agrarius chejuensis and $A$. agrarius coreae, 14 parts were relatively longer in $A$. agrarius coreae than in $A$. agrarius chejuensis (Fig. 4 and Table 3 ). In the remaining parts, basilar length, nasal length and length of upper diastema were longer in $A$. agrarius chejuensis, showing relatively longer rostrum in this subspecies.

Table 4. Measurements (mm, mean $\pm \mathrm{SD}$ ) of the skull in two subspecies of Apodemus agrarius and three other Apodemus species

\begin{tabular}{|c|c|c|c|c|c|}
\hline Measurements & A. a chejuensis & A. a coreae & A. speciosus & A. argenteus & A. semotus \\
\hline GLS: greatest length of skull & $28.82 \pm 1.07$ & $25.04 \pm 1.26$ & $29.54 \pm 1.54$ & $23.22 \pm 0.61$ & $26.58 \pm 1.95$ \\
\hline CL: condylobasal length & $26.65 \pm 1.16$ & $23.32 \pm$ & $27.33 \pm 1.38$ & \pm 0.57 & $24.52 \pm$ \\
\hline Ratio to GLS & $92.47 \%$ & $93.12 \%$ & $92.50 \%$ & $93.52 \%$ & $92.24 \%$ \\
\hline BL: basilar length & $22.34 \pm 1.03$ & $19.39 \pm 1.16$ & $23.31 \pm 1.20$ & $17.73 \pm 0.60$ & $20.07 \pm 1.90$ \\
\hline Ratio to GLS & $77.50 \%$ & $77.43 \%$ & $78.90 \%$ & $76.37 \%$ & $75.48 \%$ \\
\hline PL: palatilar length & $12.52 \pm 0.58$ & $10.94 \pm 0.53$ & $13.15 \pm 0.72$ & $9.80 \pm 0.32$ & $11.27 \pm 1.18$ \\
\hline Ratio to GLS & $43.43 \%$ & $43.69 \%$ & $44.50 \%$ & $42.23 \%$ & $42.40 \%$ \\
\hline NL: nasal length & $11.07 \pm 0.62$ & $9.35 \pm 0.47$ & $11.42 \pm 0.88$ & $7.97 \pm 0.51$ & $10.46 \pm 1.53$ \\
\hline Rati & $38.39 \%$ & $37.33 \%$ & $38.66 \%$ & $34.32 \%$ & 39. \\
\hline FL: frontal length & $8.93 \pm 0.51$ & $8.33 \pm 0.60$ & $9.19 \pm 0.46$ & $7.76 \pm 0.35$ & $7.98 \pm 0.67$ \\
\hline Rati & $30.98 \%$ & $33.26 \%$ & $31.10 \%$ & $33.42 \%$ & $30.01 \%$ \\
\hline PrL: parietal length & $5.06 \pm 0.31$ & $4.65 \pm 0.29$ & $5.40 \pm 0.33$ & $5.00 \pm$ & .58 \\
\hline Ratio to GLS & $17.55 \%$ & $18.56 \%$ & $18.26 \%$ & $21.55 \%$ & $18.14 \%$ \\
\hline IL: interparietal length & $3.34 \pm 0.33$ & $3.18 \pm 0.34$ & $3.70 \pm 0.37$ & $3.26 \pm 0.25$ & $6 \pm 0.33$ \\
\hline Ratio to & $11.60 \%$ & $12.68 \%$ & $12.52 \%$ & $14.05 \%$ & $12.65 \%$ \\
\hline LIF: length of incisi & \pm 0.38 & $4.64 \pm 0.33$ & $5.61 \pm 0.35$ & $4.38 \pm 0.21$ & $2 \pm 0.50$ \\
\hline o GLS & $18.44 \%$ & $18.54 \%$ & $18.99 \%$ & $18.87 \%$ & $18.88 \%$ \\
\hline ABL: auditory bulla length & $5.39 \pm 0.24$ & $4.97 \pm 0.24$ & $5.83 \pm 0.29^{\circ}$ & $4.70 \pm 0.44$ & $4.78 \pm 0.44$ \\
\hline GLS & $18.71 \%$ & $19.86 \%$ & $19.73 \%$ & $20.26 \%$ & $17.99 \%$ \\
\hline ZB: zygomatic breadth & $13.31 \pm 0.54$ & $12.08 \pm 0.50$ & $14.62 \pm 0.65$ & $11.57 \pm 0.31$ & $12.57 \pm 0.91$ \\
\hline Ratio to GLS & $46.18 \%$ & $48.23 \%$ & $49.50 \%$ & $49.84 \%$ & $47.28 \%$ \\
\hline IB: interorbital breadth & $4.92 \pm 0.21$ & $4.46 \pm 0.21$ & $4.98 \pm 0.20$ & $4.19 \pm 0.23$ & $4.60 \pm 0.29$ \\
\hline Ratio to GLS & $17.07 \%$ & $17.80 \%$ & $16.85 \%$ & $18.03 \%$ & $17.29 \%$ \\
\hline BR: breadth of rostrum & $4.48 \pm 0.26$ & $4.17 \pm 0.22$ & $4.54 \pm 0.33$ & $3.57 \pm 0.15$ & $4.17 \pm 0.39$ \\
\hline Ratio to GLS & $15.55 \%$ & $16.67 \%$ & $15.35 \%$ & $15.38 \%$ & $15.70 \%$ \\
\hline BOF: breadth of occipital foramen & $4.82 \pm 0.21$ & $4.48 \pm 0.28$ & $5.27 \pm 0.48$ & $4.97 \pm 0.52$ & $4.66 \pm$ \\
\hline Ratio to GLS & $16.71 \%$ & $17.88 \%$ & $17.84 \%$ & $21.39 \%$ & $17.53 \%$ \\
\hline LUM: length of upper molar series & $4.17 \pm 0.18$ & $3.99 \pm 0.15$ & $4.41 \pm 0.22$ & $3.69 \pm 0.15$ & $3.96 \pm 0.38$ \\
\hline Ratio to GLSs & $14.46 \%$ & 15.95 & 14.93 & 15.88 & $14.91 \%$ \\
\hline LUD: length of upper diastema & $8.15 \pm 0.41$ & $6.82 \pm 0.49$ & $8.04 \pm 0.61$ & $6.14 \pm 0.33$ & $6.89 \pm 0.77$ \\
\hline Ratio to GLS & 28.29 & 27.22 & $27.21 \%$ & $26.47 \%$ & $25.93 \%$ \\
\hline LM: length of mandible & $14.47 \pm 0.64$ & $12.64 \pm 0.72$ & $15.98 \pm 0.86$ & $12.12 \pm 0.44$ & $13.90 \pm 1.21$ \\
\hline Ratio to GLS & $50.22 \%$ & $50.50 \%$ & $54.11 \%$ & $52.19 \%$ & $52.29 \%$ \\
\hline HM: height of mandible & $7.68 \pm 0.36$ & $6.43 \pm 0.46$ & $7.69 \pm 0.60$ & $6.20 \pm 0.32$ & $6.93 \pm 0.66$ \\
\hline Ratio to GLS & $26.65 \%$ & $25.70 \%$ & $26.02 \%$ & $26.72 \%$ & $26.06 \%$ \\
\hline LLM: length of lower molar series & $4.19 \pm 0.24$ & $3.93 \pm 0.17$ & $4.50 \pm 0.23$ & $3.64 \pm 0.14$ & $4.04 \pm 0.36$ \\
\hline Ratio to GLS(\%) & $14.54 \%$ & $15.70 \%$ & $15.23 \%$ & $15.69 \%$ & $15.20 \%$ \\
\hline
\end{tabular}


To evaluate the proportional differences among five species/subspecies, we compared regression lines of 18 lengths of the skull against the greatest cranial length. A. speciosus had many characters demonstrating significant differences compared to other species/subspecies with differences in 14 to 16 parts (Table 4). In contrast, $A$. $a$. chejuensis showed sereral characters indicating significant differences compared to other species/subspecies (Table 4). Significant differences were observed between $A$. agrarius chejuensis and $A$. argenteus in 6 parts, between $A$. agrarius chejuensis and A. semotus in 7 parts, and between $A$. agrarius chejuensis and $A$. agrarius coreae in 8 parts. Thus, there is no evidence indicating skulls of $A$. agrarius chejuensis and $A$. agrarius coreae were similar shape.

Pronounced sexual dimorphism in cranial measurements was observed in $A$. agrarius coreae and $A$. semotus, in which the males were larger than females, while the others show little dimorphism (Table 5). Thus, the skull of $A$. agrarius coreae was sexually dimorphic, different from $A$. agrarius chejuensis.

Table 5. Statistical differences ( $t$-test) among regression lines of two subspecies of Apodemus agrarius and other three Apodemus species for each of 18 skull characters against the greatest length of the skull (GLS). $\mathrm{CH}=\mathrm{A}$. a. chejuensis, $\mathrm{CO}=\mathrm{A}$. a. coreae, $\mathrm{SP}=A$. speciosus, $\mathrm{AR}=A$. argenteus, $\mathrm{SE}=A$. semotus. Differences of the regression coefficients $(\mathrm{R})$ and the Y-intercepts (I) are shown for dyad with $p<0.05$, Y-intercepts were tested for dyad with equal regression coefficients. Cite Table 3 for the abbreviations of skull characters

\begin{tabular}{|c|c|c|c|c|c|c|c|c|c|c|c|c|c|c|c|c|c|c|}
\hline Dyad & $\mathrm{CL}$ & $\mathrm{BL}$ & $\mathrm{PL}$ & NL & $\mathrm{FL}$ & PrL & IL & LIF & $\mathrm{ABL}$ & $\mathrm{ZB}$ & IB & $\mathrm{BR}$ & $\mathrm{BOF}$ & LUM & LUD & $\mathrm{LM}$ & $\mathrm{HM}$ & $L \mathrm{LM}$ \\
\hline $\mathrm{CH}: \mathrm{CO}$ & $\mathrm{R}$ & & & $\mathrm{R}$ & I & & & & $\mathrm{R}$ & & I & & I & & & & I & I \\
\hline $\mathrm{CH}: \mathrm{SP}$ & $\mathrm{R}$ & $\mathrm{R}$ & I & & & I & I & I & I & I & & & I & I & I & I & I & I \\
\hline $\mathrm{CH}: \mathrm{AR}$ & $\mathrm{R}$ & & & I & & I & & & & & & I & & I & & & & I \\
\hline $\mathrm{CH}: \mathrm{SE}$ & & & & I & I & & & & $\mathrm{R}$ & & & $\mathrm{R}$ & & & I & I & & $\mathrm{R}$ \\
\hline $\mathrm{CO}: \mathrm{SP}$ & & I & I & I & $\mathrm{R}$ & I & $\mathrm{R}$ & I & $\mathrm{R}$ & I & I & & I & I & & I & & I \\
\hline $\mathrm{CO}: \mathrm{AR}$ & & & I & I & & I & & & & & I & I & I & I & & I & I & I \\
\hline $\mathrm{CO}: \mathrm{SE}$ & & I & $\mathrm{R}$ & $\mathrm{R}$ & I & & I & & $\mathrm{R}$ & & $\mathrm{R}$ & $\mathrm{R}$ & & I & I & I & & $\mathrm{R}$ \\
\hline SP : AR & I & I & I & I & & & I & I & & I & I & I & I & I & & I & I & I \\
\hline SP : SE & I & I & I & $\mathrm{R}$ & I & I & I & & $\mathrm{R}$ & I & $\mathrm{R}$ & $\mathrm{R}$ & $\mathrm{R}$ & $\mathrm{R}$ & $\mathrm{R}$ & I & & $\mathrm{R}$ \\
\hline $\mathrm{AR}: \mathrm{SE}$ & $\mathrm{R}$ & I & I & & I & I & & & $\mathrm{R}$ & I & & & I & & I & & I & \\
\hline
\end{tabular}

\section{Form of the upper and lower molars in the genus Apodemus}

The upper and lower molars of the Apodemus spp. were generally obtuse type with three processus constituted several cusps arraying on each molar (Fig. 5). The anterocone of the upper 2 nd and $3 \mathrm{rd}$ molars is small and the anterolingual conule, consisting of three constrictions, is continuous, forming the shape of a mountain, and the basic form was the same as the upper 1 st molar. In addition, the distances between the line linking posterior points of the incisive foramen and the line linking the anterior points of the right and left of the upper first molar teeth differs between $A$. agrarius chejuensis and $A$. agrarius coreae, being obviously longer in the former (Fig. 6; A. agrarius chejuensis: $1.11 \pm 0.21 ; A$. agrarius coreae: $0.21 \pm 0.11 ;$ A. speciosus: $1.16 \pm 0.19 ;$ A. argenteus: $0.88 \pm 0.18 ;$ A. semotus: $0.79 \pm 0.12$ ). There was significant differences among the dis- 

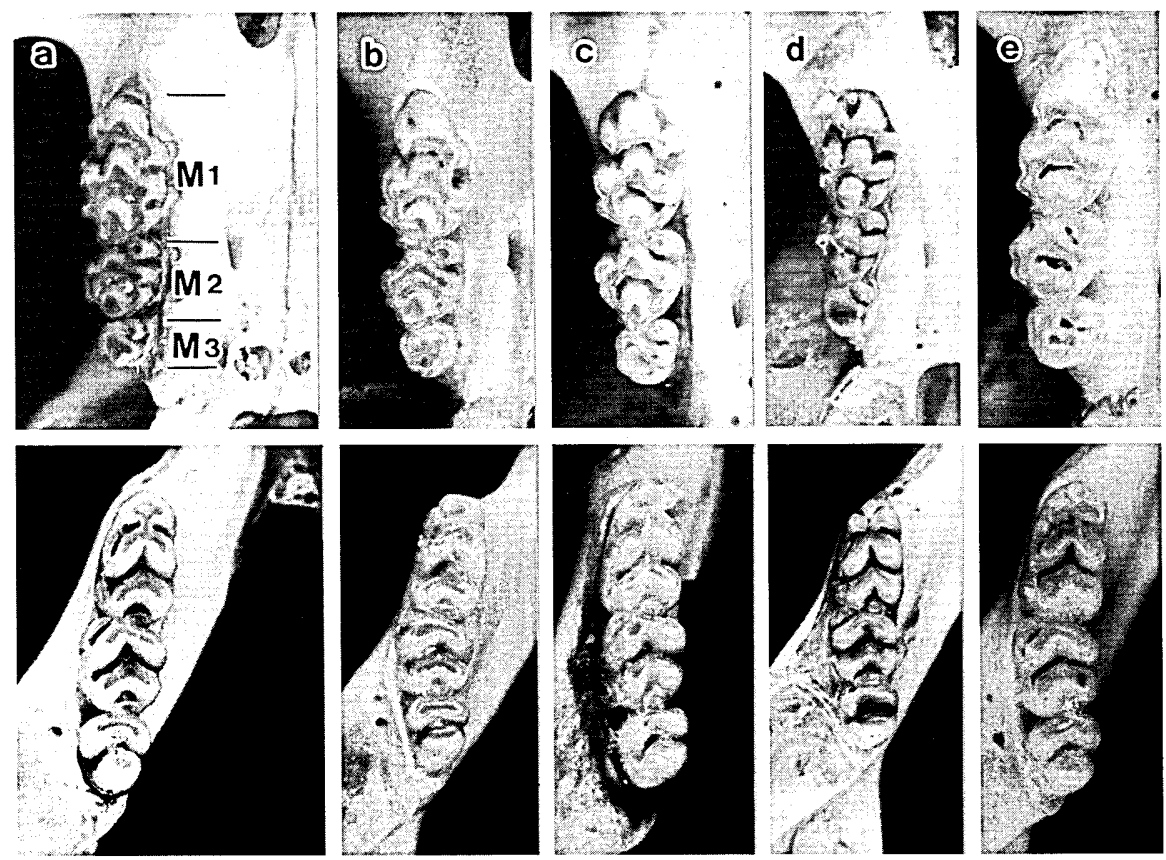

Fig. 5. Right sides of upper (upper photographs) and lower (lower photographs) molar teeth of males specimens in genus Apodemus. a) A. agrarius chejuensis; b) A. agrarius coreae; c) A. speciosus; d) A. argenteus; e) A. semotus. M1, the first upper molar; M2, the second upper molar; M3. the third upper molar. $\times 8.5$.
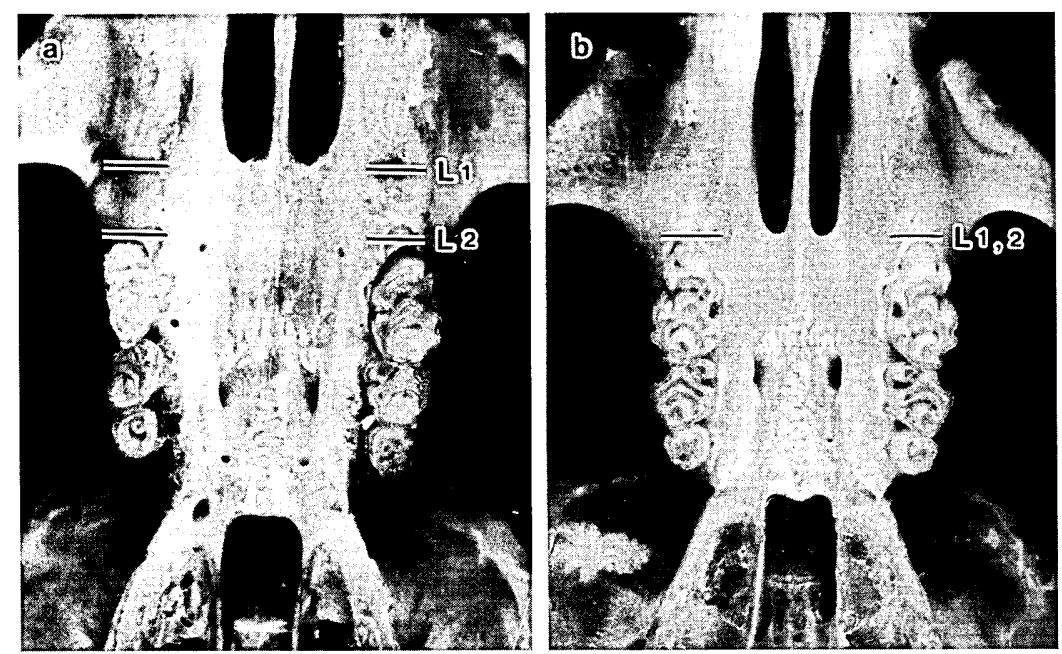

Fig. 6. Comparison of the distances between the line linking the anterior points of right and left incisive foramina (L1) and the line linking the posterior points of right and left first molar teeth (L2) of the upper jaw in a) Apodemus agrarius chejuensis and b) A. agrarius coreae. Note that two lines overlap each other in $A$. agrarius coreae. $\times 8.5$. 
tances of all of the species/subspecies (ANOVA, $F=189.4$, d.f. $=195, p<0.001$ ). The distance was significantly smaller in $A$. agrarius coreae and $A$. semotus than in the other species/subspecies (post hoc-test, $p<0.001$ ).

\section{DISCUSSION}

The degree of sexual dimorphism in the genus Apodemus differs between the subspecies and species and different results were obtained for A. agrarius, a Eurasian species which is reported to have little morphological variation (Haitlinger, 1962) and $A$. agrarius coreae, native to the Korean mainland, reported to have no sexual dimorphism (Koh, 1983). In other words, the significant differences that were observed between $A$. agrarius chejuensis and $A$. agrarius coreae in head and body length, body weight, tail length, hind foot length and ear length as well as the fact that each showed regression on different lines are good indications of the differences between the two subspecies. In addition, it can also be said that, while tail length is a sexual dimorphic character of $A$. agrarius chejuensis, the fact that the $A$. agrarius coreae did not indicate a significant difference in sexual dimorphism and the fact that the $A$. a. coreae has a lower tail ratio than $A$. agrarius chejuensis reflect differences in the living environments of these two subspecies and are interesting characters. A. agrarius chejuensis which inhabits Cheju Island, is large both in body and cranial size compared to the subspecies $A$. agrarius coreae and coincides well with corresponds well with the Island rule. A. agrarius coreae also differed in size, though basically it was expected to be much the same as A. agrarius chejuensis. As inferred from research (Yoon et al., submitted for publication) relating to biogeography, group genetic structure and speciation relating to A. agrarius native to Korea, $A$. agrarius in Korea is thought to originate in $A$. agrarius chejuensis. The two subspecies are therefore thought to have been subjected to the influence of different environmental and natural enemy factors as well as genetic relationships, causing each to evolve in different directions. In addition, dimorphism is clear in the case of the forest-dwelling $A$. semotus in terms of body size, while little was found in the case of $A$. argenteus, which is thought to reflect the different ways of life of the various species, resulting in differences in morphological expression.

Comparing the results of the Formosan wood mouse, A. semotus (Lin and Shiraishi, 1992), which has close affinity to the relative growth of the skull in A. agrarius chejuensis, there were general similarities in the growth rate coefficient and the initial growth index of each part; however, the growth rate coefficient of the breadth of the rostrum and interorbital breadth was greater in the former, while that of the zygomatics breadth and breadth of occipital foramen was smaller. In addition, it has been reported in research involving A. speciosus (Hiraiwa et al., 1958), A. agrarius (Tanaka, 1942) and A. semotus (Lin and Shiraishi, 1992) that the growth of the interorbital breadth and interparietal length is slower than that of the other parts; however, the growth rate coefficient of the breadth of rostrum and interorbital breadth is large in the case of $A$. agrarius chejuensis and the fact that, even when an adult, they continue to grow for a longer time than in in other Apodemus species is thought to be a characters of this species.

Interspecific differences in rodent crania are observed in those parts directly related to the molars and masticatory muscle, which take a form that enables adaption to the 
unique feeding habits of the animal species. The species of genus Apodemus have various feeding habits, such as A. flavicollis and A. sylvaticus of Europe (Hansson, 1971), A. speciosus, $A$. agrarius chejuensis, $A$. a. coreae and $A$. semotus, which feed on seeds and insects, and $A$. argenteus, which is insectivorous. Based on the results of a comparison of the parts of the skull between species, significant differences were found in the relationship that are greater between the two subspecies $A$. agrarius chejuensis and $A$. agrarius coreae than $A$. argenteus and $A$. semotus. Furthermore, it is thought that the distance between a line connecting the left and right rear extremities of the incisive foramen and a line connecting the left and right front extremities of the upper first molars, which is different between $A$. agrarius coreae and $A$. agrarius chejuensis, originates in the fact that the upper diastema is longer in $A$. agrarius chejuensis than in other species. Thus, in the taxonomic relationship between $A$. agrarius coreae and $A$. agrarius chejuensis, judging from the fact that there are various differences in the cranial characters, the distance between the rear extremities of the incisive foramen and front extremities of the upper first molars and the various characters of the external morphology, we have concluded that there are significant morphological differences between these two subspecies and that they have an extremely distant taxonomic relationship.

\section{REFERENCES}

Adamczewska-Andrzejewska, K. 1971 Methods of age determination on Apodemus agrarius. Ann. Zool. Fenniici, 8: 68-71

Adamczewska-Andrzejewska, K. 1973 Growth, variation and criteria in Apodemus agrarius. Acta Theriol., 18/19: 353-394

Corbet, G. B. 1978 The Mammals of the Palaearctic region: A Taxonomic Review. British museum (Natural History), Cornell University Press, London and Ithaca, 314pp.

Delany, M. J. 1970 Variation and ecology of island populations of the long-tailed field mouse Apodemus sylvaticus. Proc. Zool. Soc. Lond., 26: 283-295

Delany, M. J. and P. E. Davis 1961 Observations on the ecology and life history of the Fair Isle field mouse, Apodemus sylvaticus fridariensis (Kinnear). Symp. Zool. Soc. Lond., 136: 439-452

Gurnell, J. and C. I. Knee 1984 Determining the age of wood mice Apodemus sylvaticus. Folia Zool., 33: $339-348$

Haitlinger, R. 1962 Morphological variability in Apodemus agrarius (Pallas, 1771). Acta Theriol., 6: 239-256

Haitlinger, R. 1969 Morphological variability of the Wroclaw population of Apodemus sylvaticus (Linnaeus, 1758). Acta Theriol., 14: 285-302

Hansson, L. 1971 Small rodent food, feeding and population dynamics, A comparison between granivorous and herbivorus species in Scandinavia. Oikos, 22: 183-198

Hikida, T. and O. Murakami 1980 Age determination of the Japanese wood nuose, Apodemus speciosus. Jap. J. Ecol., 30: 109-116 (in Japanese with English synopsis)

Hiraiwa, Y. K., M. Tokuda, T. Uchida and H. Sugiyama 1958 Some small mammals from the Islands of Oki, with especial reference to detail examination of their subspecific characteristics. Sci. Bull. Fac. Agri. Kyushu., 16: 547-574 (in Japanese with English synopsis)

Hong, H. K. and U. Y. Lee 1984 Studies on the biology of Apodemus agrarius in Korea. Thesis of Incheon Univ., 6: 417-439

Imaizumi, Y. 1962 On the species formation of the Apodemus speciosus group, with special reference to the importance of relative values in classification. Bull. Nat. Sci. Mus., 5: 163-259 (in Japanese with English resume)

Johonson, D. H. and J. K. Jones Jr. 1955 Three new rodents of the genera Micromys and Apodemus from Korea. Proc. Biol. Soc. Wash., 68: 167-172 
Jones, J. K. Jr. and D. H. Johnson 1965 Synopsis of the lagomorphs and rodents of Korea. Univ. Kansas Publ. Mus. Nat. Hist., 16: 357-107

Koh, H. S. 1983 A study of age variation and secondary sexual dimorphism in morphometric characters of Korean rodents: I. An analysis on striped field mice, Apodemus agrarius coreae from, Chongju. Kor J. Zool., 26: 125-134

Koh, H. S. 1986 Geographic variation of morphometric characters among three subspecies of striped field mice, Apodemus agrarius Pallas (Muridae, Rodentia), from Korea. Kor. J. Zool., 29: 272-282

Koh, H. S. 1991 Morphometric analyses with eight subspecies of striped field mice, Apodemus agrarius Pallas (Rodentia, Mammalia), in Asia: The taxonomic status of subspecies chejuensis at Cheju island, Korea. Kor. J. Syst. Zool., 7: 179-188

Koh, H. S. and B. S. Yoo 1992 Variation of mitochondrial DNA in two subspecies of striped field mice, Apodemus agrarius coreae and Apodemus agrarius chejuensis, from Korea. Kor. J. Zool., 35: 332-338

Kuroda, N. 1934 Korean mammals preserved in the collection of Marquis Yamashina, 16: 229-239

Lin, L. K. and S. Shiraishi. 1992 Skull growth and variation in the Formosan Wood Mouse, Apodemus semotus. J. Fac. Agr. Kyushu Univ., 37: 51-69

Miyao, T. and T. Mōri. 1968 Studies on the geographical variation of the small mammals in Japanese Islands. III. Geographical variation of body sizes in Apodemus argenteus. J. Growth, 7: 1-8 (in Japanese with English summary)

Miyao, T., T. Mōri and T. Morozumi 1968 Studies on Apodemus speciosus from the island of Oki. Honyurui Kagaku (Mammalian Science), 16: 37-51 (in Japanese with English summary)

Musser, G. G. and M. D. Carleton 1993 Family Muridae. In "Mammal Specie of The World", 2nd ed. by D. E. Wilson and D. M. Reeder, Smithonian Institution Press, Washington \& London, pp. 501-755

Sikorski, M. D. 1982 Craniometric variation of Apodemus agrarius (Pallas, 1771) in urban green areas. Acta Theriol., 27: 71-81

Tanaka, R. 1942 A biostatistical analysis of Apodemus agrarius from Formosa with special reference to its systematic characters. Mem. Fac. Sci. Agr. Taihoku Imp. Univ. Formosa, Japan, 23: 212-282

Thomas, O. 1907 The Duke of Bedford's zoological exploration in eastern Asia. II. List of small mammals from Korea and Quelpart. Proc. Zool. Soc. London, 1906: 858-865

Tsuchiya, K. 1984 Notes on the development and utilization of characteristics in Apodemus spp. (A) Comprehensive study in the Ministry of Education; The development and utilization of characteristics of newly domesticated animals, 17-25 (in Japanese)

Tsuchiya, K. 1985. Notes on breeding of Apodemus spp. For laboratory animals. Bulletin of Kyushu Branch, Japan Experimental Animal Technician Association, 8: 4-12 (in Japanese)

Won, P. H. 1961 Studies on the ecological observation of rodentia in Manchuria and Korea (Part I). Zool. Inst., Liberal Arts Coll., Dong Kook Univ., Seoul, 1-92

Yoon, M. H., I. Kim, H. S. Oh and C. J. Phillips Biography, genetic structure and speciation in the striped field mouse, Apodemus agrarius in southern Korea (submitted for publication)

Yoshida, H. 1983 A note on the morphology of Apodemus speciosus collected in the mountain districts in Kyushu. Biologia Fukuokana, 23: 19-24 (in Japanese)

Yoshida, H. 1984 A note on the morphology of Apodemus argenteus collected in the mountain districts in Kyushu. Biologia Fukuokana, 24: 22-27 (in Japanese)

Zar, J. H. 1999 Biostatistical Analysis. 4th ed. Prentice-Hall, Inc., Upper Saddle River, New Jersey, 718 $\mathrm{pp}$ 